\title{
POST-CORONAVIRUS DISEASE 2019 DE QUERVAIN'S THYROIDITIS - A CASE REPORT AND LITERATURE REVIEW
}

\author{
MOHAMAD SAFWAN*, VIJAYAN KN, NAJEEB, JITHU TG
}

Department of General Surgery, Kerala Institute of Medical Science, Trivandrum, Kerala, India. Email: mdsafwanmbbs@gmail.com

Received: 31 January 2020, Revised and Accepted: 20 February 2021

\section{ABSTRACT}

De Quervain's thyroiditis, also known as subacute thyroiditis (SAT), is a self-limiting inflammatory thyroid disease typically occurring a few weeks after a respiratory viral infection. A 29-year-old female with no comorbidities presented with persistent fever, neck pain, and swelling of 10 days duration. She also had tremors, fatigue, and palpitation. A careful enquiry revealed that she had been diagnosed with coronavirus disease 2019 (COVID-19) infection 6 weeks ago and had recovered uneventfully with conservative management. Her laboratories showed leukocytosis, elevated erythrocyte sedimentation rate, and C-reactive protein. Thyroid function tests (TFTs) yielded low thyroid-stimulating hormone, and high T3 and free T4. Ultrasonography neck was suggestive of thyroiditis. Thyroid scintigraphy demonstrated very low technetium uptake which confirmed SAT. Her symptoms ameliorated with nonsteroidal anti-inflammatory drug and beta-blockers and her TFTs improved during follow-up. We report this as emerging sequelae of COVID-19 infection. A persistent fever and neck pain following recent COVID-19 infection should alert clinician toward the possibility of de Quervain's thyroiditis following severe acute respiratory syndrome coronavirus 2.

Keywords: Coronavirus disease 2019 infection, De Quervain's thyroiditis, Severe acute respiratory syndrome coronavirus 2, Subacute thyroiditis, Tender goiter.

(C) 2021 The Authors. Published by Innovare Academic Sciences Pvt Ltd. This is an open access article under the CC BY license (http://creativecommons. org/licenses/by/4.0/) DOI: http://dx.doi.org/10.22159/ijms.2021v9i2.40956. Journal homepage: https://innovareacademics.in/journals/index.php/ijms

\section{INTRODUCTION}

The World Health Organization declared coronavirus disease 2019 (COVID-19) as a global pandemic in March 2020. It is caused by severe acute respiratory syndrome coronavirus 2 (SARS-CoV-2) infection which primarily manifests with acute respiratory symptoms. It is well known to produce extrapulmonary symptoms, either at the initial presentation or as a later complication. De Quervain's thyroiditis duet to post-COVID-19 sequelae is rarely reported.

Hereby, we report a case of subacute (de Quervain's) thyroiditis triggered by recent SARS-CoV-2 infection. To the best of our knowledge, eight cases of subacute thyroiditis (SAT) following COVID-19 infection have been reported so far in world literature [1-5], none of them is from the Indian population. The purpose of presenting this case is to alert clinician about this new complication following COVID-19 as well as identify the thyrotoxic symptoms which may be missed during the current devastating pandemic.

\section{CASE REPORT}

Patient consent was taken for publishing purposes. A 29-year-old female medical practitioner with no comorbidities presented to the emergency room with persistent high-grade fever and worsening swelling of 10 days duration associated with pain which was radiating from the left side to right side of the neck. The pain was exacerbated by swallowing, bending, and turning the neck to the side. History of bilateral hand tremors, fatigue, and palpitations for 4 days was also elicited.

A detailed enquiry revealed that 6 weeks before the onset of symptoms, she had suffered several days of fever, cough, and other flu-like symptoms. Reverse transcriptase-polymerase chain reaction by nasopharyngeal swab was positive for SARS-CoV-2 during that time. In about a week of conservative treatment, she recovered from her symptoms uneventfully.

She denied the history of trauma, radiation, drug intake like amiodarone, lithium, or intravenous contrast and no similar illness in the past. Physical examination demonstrated tachycardia, fine tremor of extremities, and diffuse and tender goiter. There was no cervical lymphadenopathy, eye signs, thrill, or bruit over the thyroid gland. Oropharyngeal and general systems examination were normal.

Thyroid function tests (TFTs) showed a very low thyroid-stimulating hormone (TSH) $(0.007 \mathrm{microU} / \mathrm{L})$ and high T3 $(5.05 \mathrm{ng} / \mathrm{ml})$ and free T4 $(7.77 \mathrm{ng} / \mathrm{dl})$ which confirmed hyperthyroidism.

Total leukocyte count (15,100/cu.mm), erythrocyte sediment rate (ESR) $(70 \mathrm{~mm} / \mathrm{hr})$, and C-reactive protein (CRP) $(172 \mathrm{mg} / \mathrm{L})$ were elevated.

Microsomal antibodies, thyroglobulin antibodies, and TSH receptor antibodies were negative.

Ultrasound (USG) neck demonstrated enlarged heterogeneously hypoechoic left lobe of thyroid and isthmus with normal vascularity, and bulky right lobe of thyroid with few ill-defined hypoechoic areas which suggestive of thyroiditis.

Technetium pertechnetate thyroid scan exhibits no significant uptake of the radiotracer (Fig. 1) which confirmed SAT.

The diagnosis of SAT was suspected by her clinical presentation and recent COVID-19 infection and it was corroborated with her laboratory findings and the absent technetium pertechnetate uptake on a thyroid scan.

She was started on oral indomethacin $25 \mathrm{mg}$ and propanol $40 \mathrm{mg}$ thrice daily. Her symptoms subsided and she was discharged after 3 days of hospitalization. On 3-week follow-up, she attained remission from her symptoms with improvement in TFT (TSH - 0.01 microU/L, free T3 $1.1 \mathrm{ng} / \mathrm{ml}$, and FT4 - $1.1 \mathrm{ng} / \mathrm{dl}$ ).

\section{DISCUSSION}

SAT is the most common cause of painful thyroid disease, which resulting from the release of preformed thyroid hormones after 2-8 weeks of viremia in genetically predisposed individuals and has a strong association with HLA B35 in many generic groups $[6,7]$. 


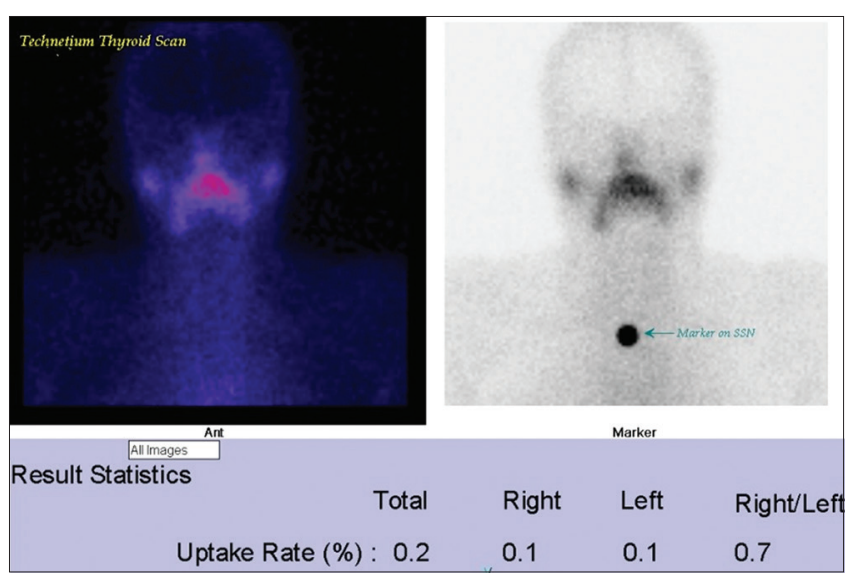

Fig. 1: Tc99 thyroid scan shows no uptake of the radiotracer
It was first defined by Friz De Quervain in 1904. He distinguished this disease pathologically from other forms of thyroiditis. De Quervain thyroiditis is also called subacute granulomatous thyroiditis, subacute non-suppurative thyroiditis, giant cell thyroiditis, pseudogranulomatous thyroiditis, pseudo-tuberculous thyroiditis, or struma granulomatosa [7]

The incidence is 12.1 cases per 100,000 /year affecting younger and middle adulthood age groups with female preponderance. Disease frequency decreases with increasing age [8,9]. Viruses such as mumps, measles, adenovirus, Epstein-Barr virus, Coxsackie virus, influenza, Echovirus, and Enterovirus are commonly associated virus causing SAT [9].

However, the incidence of novel COVID-19-induced SAT appears to be reporting more during the current pandemic situation. The reported case of SAT following COVID-19 infection is enumerated in Table 1.

Table 1: List of SAT cases following COVID-19 infection reported in the literature to date

\begin{tabular}{|c|c|c|c|c|c|c|c|c|c|}
\hline References & Current case & [1] & [2] & [2] & [2] & [2] & [3] & [4] & [5] \\
\hline Age and sex & $\begin{array}{l}29 \text { years, } \\
\text { female }\end{array}$ & $\begin{array}{l}18 \text { years, } \\
\text { female }\end{array}$ & $\begin{array}{l}38 \text { years, } \\
\text { female }\end{array}$ & $\begin{array}{l}29 \text { years, } \\
\text { female }\end{array}$ & $\begin{array}{l}29 \text { years, } \\
\text { female }\end{array}$ & $\begin{array}{l}46 \text { years, } \\
\text { female }\end{array}$ & $\begin{array}{l}43 \text { years, } \\
\text { female }\end{array}$ & $\begin{array}{l}41 \text { years, } \\
\text { female }\end{array}$ & $\begin{array}{l}37 \text { years, } \\
\text { male }\end{array}$ \\
\hline $\begin{array}{l}\text { Past h/o } \\
\text { thyroid } \\
\text { disease }\end{array}$ & Nil & Nil & Nil & Nil & Nil & Nil & Nil & Nil & Nil \\
\hline $\begin{array}{l}\text { Type of } \\
\text { COVID-19 } \\
\text { test }\end{array}$ & Swab & Swab & Swab & Swab & Swab & Swab & Swab & Antibody & Swab \\
\hline $\begin{array}{l}\text { Time of } \\
\text { onset } \\
\text { between } \\
\text { COVID-19 } \\
\text { infection and } \\
\text { SAT features }\end{array}$ & 45 days & 17 days & 16 days & 30 days & 36 days & 20 days & 40 days & 14 days & 30 days \\
\hline $\begin{array}{l}\text { Presenting } \\
\text { SAT } \\
\text { symptoms }\end{array}$ & $\begin{array}{l}\text { Neck pain, } \\
\text { fever, } \\
\text { palpitation, } \\
\text { tremor, } \\
\text { anxiety } \\
\text { tender } \\
\text { thyromegaly }\end{array}$ & $\begin{array}{l}\text { Neck pain, } \\
\text { fever, } \\
\text { typical } \\
\text { symptoms } \\
\text { of SAT }\end{array}$ & $\begin{array}{l}\text { Neck pain, } \\
\text { fever, } \\
\text { typical } \\
\text { symptoms } \\
\text { of SAT }\end{array}$ & $\begin{array}{l}\text { Neck pain, } \\
\text { typical } \\
\text { symptoms of } \\
\text { SAT }\end{array}$ & $\begin{array}{l}\text { Neck pain, } \\
\text { typical } \\
\text { symptoms of } \\
\text { SAT }\end{array}$ & $\begin{array}{l}\text { Neck pain, } \\
\text { fever, } \\
\text { typical } \\
\text { symptoms } \\
\text { of SAT }\end{array}$ & $\begin{array}{l}\text { Neck pain, } \\
\text { typical } \\
\text { symptoms } \\
\text { of SAT }\end{array}$ & $\begin{array}{l}\text { Tender neck } \\
\text { swelling, } \\
\text { neck pain, } \\
\text { fever, typical } \\
\text { symptoms of } \\
\text { SAT }\end{array}$ & $\begin{array}{l}\text { Neck pain, } \\
\text { typical } \\
\text { symptoms of } \\
\text { SAT }\end{array}$ \\
\hline TFT and & TSH - 0.007 & TSH - & TSH - 0.1 & TSH -0.01 & & TSH - & TSH - & TSH - 0.01 & TSH - 0.01 \\
\hline thyroid & FT4 - 7.77 & 0.004 & FT4 - 29.3 & FT4 - 31.8 & available & 0.01 & 0.006 & FT4 - 60.63 & FT4 - 2.3 \\
\hline antibodies & $\mathrm{tT} 3-5.05$ & FT4 - 27.2 & FT3 - 8.0 & FT3 - 8.9 & & FT4 - 27.8 & FT4 - 27.2 & $\mathrm{tT} 3-3.39$ & tT3 - 202 \\
\hline & $\begin{array}{l}\text { TPOAb - } \\
\text { Thyroglobulin } \\
\text { Ab- } \\
\text { TSHAb- }\end{array}$ & $\begin{array}{l}\text { FT3 - } 8.7 \\
\text { TsAb+ } \\
\text { TPOAb- } \\
\text { TRAb- }\end{array}$ & $\begin{array}{l}\text { TsAb- } \\
\text { TPOAb- } \\
\text { TRAb- }\end{array}$ & $\begin{array}{l}\text { TsAb+ } \\
\text { TPOAb- } \\
\text { TRAb- }\end{array}$ & & $\begin{array}{l}\text { FT3 - } 6.9 \\
\text { TRAb- }\end{array}$ & $\begin{array}{l}\text { FT3 - } 8.7 \\
\text { TsAb+ } \\
\text { TPOAb- } \\
\text { TRAb- }\end{array}$ & $\begin{array}{l}\text { TsAb- } \\
\text { TPOAb- } \\
\text { TRAb- }\end{array}$ & $\begin{array}{l}\text { TPOAb- } \\
\text { TSI- }\end{array}$ \\
\hline $\begin{array}{l}\text { Ultrasound } \\
\text { thyroid } \\
\text { with color } \\
\text { Doppler } \\
\text { with features } \\
\text { of goiter, } \\
\text { hypoechoic } \\
\text { areas, and } \\
\text { absent } \\
\text { or low } \\
\text { vascularity }\end{array}$ & Present & Present & Present & Present & Present & Present & Present & Present & Present \\
\hline $\begin{array}{l}\text { Tc } 99 \mathrm{~m} \\
\text { thyroid } \\
\text { Scintigraphy }\end{array}$ & No uptake & - & - & No uptake & - & - & $\begin{array}{l}\text { Very low } \\
\text { uptake }\end{array}$ & - & - \\
\hline Treatment & $\begin{array}{l}\text { NSAID beta } \\
\text {-blocker }\end{array}$ & Steroid & Steroid & $\begin{array}{l}\text { Steroid, beta- } \\
\text { blocker }\end{array}$ & NSAID & Steroid & Steroid & $\begin{array}{l}\text { Steroid, } \\
\text { NSAID }\end{array}$ & $\begin{array}{l}\text { Steroid, beta } \\
\text {-blocker }\end{array}$ \\
\hline Follow-up & $\begin{array}{l}\text { Improvement } \\
\text { in TFT }\end{array}$ & Normal & Normal & $\begin{array}{l}\text { Subclinical } \\
\text { hypothyroidism }\end{array}$ & $\begin{array}{l}\text { Subclinical } \\
\text { hypothyroidism }\end{array}$ & Normal & Normal & $\begin{array}{l}\text { Improvement } \\
\text { in TFT }\end{array}$ & $\begin{array}{l}\text { Subclinical } \\
\text { hypothyroidism }\end{array}$ \\
\hline
\end{tabular}

TFT: Thyroid function test, SAT: Subacute thyroiditis, COVID-19: Coronavirus disease 2019, TSH: Thyroid-stimulating hormone, NSAID: Nonsteroidal anti-inflammatory drug 
Relationship between thyroid and COVID-19 infection

Due to the increased expression of angiotensin-converting enzyme 2 and transmembrane protease serine 2 levels in the thyroid gland than in the lungs, these act as the key routes for virus entry into host cells in susceptible patients. Abnormal immunological response and cytokine storm due to COVID-19 may also provoke thyroiditis [10]

The natural history of SAT involves four phases, starting with a hyperthyroid phase and then followed by a transient asymptomatic euthyroid phase, a hypothyroid phase, and a final phase euthyroid phase on recovery. Each phase lasts for approximately 4-6 months [11]

The disease classically presents as anterior lower neck pain which radiates to upper neck, throat, jaw, or ears and exacerbated by moving the head, swallowing, or coughing. Associated flu-like symptoms such as fever, malaise, fatigue, and myalgia may be present. Diffuse tender thyromegaly with clinical features of hyperthyroidism such as tachycardia, tremor, weight loss, palpitation, and anxiety during the initial stage is common at presentation [12].

Diagnosis is mainly based on classical clinical history and physical and laboratory findings. TFTs should be done initially in all patients with suspected SAT followed by ESR and CRP level. Serum anti-thyroid peroxidase, anti-thyroglobulin antibodies, and TSH receptor antibodies are usually absent or present at low titer. Serum thyroglobulin levels may be elevated due to follicular destruction [12]

Radioactive uptake or technetium (99mTc) pertechnetate thyroid scan during the hyperthyroid phase helps to confirm the diagnosis. It is due to destruction of thyroid follicles with iodine trap defect. USG thyroid may help to assess the size, nature, echogenicity, and vascularity of the thyroid gland[12].

Characteristics features of Graves' disease such as exophthalmos, pretibial myxedema, thrill, or bruit over thyroid gland are absent. A low radioactive iodine uptake study, high ESR, and/or high CRP may help to differentiate hyperthyroidism due to SAT from Grave's disease, which has high iodine uptake with normal ESR and CRP. Decreased vascular flow patterns in color Doppler USG during the hyperthyroid phase of SAT also aid to distinguish it from Graves' disease, which has increased flow [12]. USG-guided fine-needle aspiration cytology is rarely needed in doubtful cases with unilateral thyroid involvement, which helps to distinguish thyroid abscess, hemorrhage, or thyroid lymphoma from SAT [12]

Septic workup is usually needed in patients with fever, and a thorough cardiology evaluation may be warranted if tachycardia is present.

Treatment should aim at alleviating anterior neck pain and ameliorating thyrotoxic symptoms. Mild-to-moderate pain is usually managed with nonsteroidal anti-inflammatory drugs and salicylates. Severe pain can be managed with steroids, which provides a dramatic response within 24-48 h. Hyperthyroid symptoms are best treated with beta-blockers such as propanol or atenolol till the free T4 level returns to normal [13].

Hypothyroid phase lasts for shorter periods, and with milder symptoms, and hence, treatment is not often required. However, patients with moderate-to-severe symptoms can be managed with thyroxine till the
TSH level returns to normal. In a rare patient with recurrent relapse and distressing local symptoms despite sufficient treatment, thyroidectomy may be indicated [13].

Regular TFT monitoring should be done every 2-8 weeks to understand the natural history of the disease and yearly thereon [13]. Even though we could not directly isolate the COVID-19 virus in thyroid tissue, current epidemiological and serological reports of our patient substantiate viral infection 4 weeks before the onset of SAT.

\section{CONCLUSION}

The clinician should have a strong suspicion of SAT in any patient presenting with persistent neck pain and odynophagia despite the remission of COVID-19 symptoms. Such individuals should be screened by TFTs, ESR, CRP, and thyroid imaging (USG or scintigraphy). Early identification and anti-inflammatory treatment often result in good outcomes.

\section{ACKNOWLEDGMENTS}

We would like to thank Dr. Thusanth Thomas (endocrinologist), Dr. Muhammed Irfan KPC, and Dr. Melvin Varghese for helping us.

\section{REFERENCES}

1. Brancatella A, Ricci D, Viola N, Sgrò D, Santini F, Latrofa F. Subacute thyroiditis after sars-COV-2 infection. J Clin Endocrinol Metab 2020;105:dgaa276.

2. Brancatella A, Ricci D, Cappellani D, Viola N, Sgrò D, Santini F, et al. Is subacute thyroiditis an underestimated manifestation of SARSCoV-2 infection? Insights from a case series. J Clin Endocrinol Metab 2020;105:dgaa537.

3. Ruggeri RM, Campennì A, Siracusa M, Frazzetto G, Gullo D. Subacute thyroiditis in a patient infected with SARS-COV-2: An endocrine complication linked to the COVID-19 pandemic. Hormones (Athens) 2020;20:219-21.

4. Khatri A, Charlap E, Kim A. Subacute thyroiditis from COVID-19 infection: A case report and review of literature. Eur Thyroid J 2020;9:325-9.

5. Chong WH, Shkolnik B, Saha B, Beegle S. Subacute thyroiditis in the setting of Coronavirus disease 2019. Am J Med Sci 2020. Doi: 10.1016/j.amjms.2020.09.011.

6. Desailloud R, Hober D. Viruses and thyroiditis: An update. Virol J 2009;6:5.

7. Engkakul P, Mahachoklertwattana P, Poomthavorn P. Eponym: De quervain thyroiditis. Eur J Pediatr 2011;170:427-31.

8. Fatourechi V, Aniszewski JP, Fatourechi GZ, Atkinson EJ, Jacobsen SJ. Clinical features and outcome of subacute thyroiditis in an incidence cohort: Olmsted county, minnesota, study. J Clin Endocrinol Metab 2003;88:2100-5.

9. Bindra A, Braunstein GD. Thyroiditis. Am Fam Physician 2006;73:1769-76.

10. Scappaticcio L, Pitoia F, Esposito K, Piccardo A, Trimboli P. Impact of COVID-19 on the thyroid gland: An update. Rev Endocr Metab Disord 2020;1-13. Doi: 10.1007/s11154-020-09615-z.

11. Fatourechi V, Aniszewski JP, Fatourechi GZ, Atkinson EJ, Jacobsen SJ. Clinical features and outcome of subacute thyroiditis in an incidence cohort: Olmsted county, minnesota, study. J Clin Endocrinol Metab 2003;88:2100-5.

12. Slatosky J, Shipton B, Wahba H. Thyroiditis: Differential diagnosis and management. Am Fam Physician 2000;61:1047-52, 1054.

13. Volpé R. The management of subacute (DeQuervain's) thyroiditis. Thyroid 1993;3:253-5. 